\title{
Modeling and Control of EGR on Marine Two-Stroke Diesel Engines
}

\author{
Xavier Llamas
}

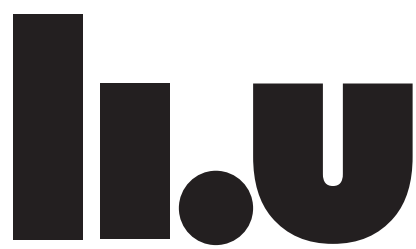

LINKÖPING UNIVERSITY

Department of Electrical Engineering

Linköping University

SE-581 83 Linköping, Sweden

Linköping 2018 
Linköping studies in science and technology. Dissertations, No. 1904

Modeling and Control of EGR on Marine Two-Stroke Diesel Engines

Xavier Llamas

ISBN 978-91-7685-368-9

ISSN 0345-7524

(C) 2018 Xavier Llamas, unless otherwise noted. All rights reserved.

Xavier Llamas

xavier.llamas.comellas@liu.se

www. vehicular.isy.liu.se

Division of Vehicular Systems

Department of Electrical Engineering

Linköping University

SE-581 83 Linköping

Sweden

The cover: The photo in the background shows several merchant ships arriving and leaving the Port of Barcelona. Several pictures were used to create the cover photo. All these images were taken by the author of the dissertation on board of a plane, seconds before landing at Barcelona Airport in May 2016. The author would like to thank Albert Escànez for doing an excellent job editing the images and designing the cover.

Typeset with $\mathrm{LT}_{\mathrm{EX}} 2 \varepsilon$

Printed by LiU-Tryck, Linköping, Sweden 2018 


\section{Abstract}

The international marine shipping industry is responsible for the transport of around $90 \%$ of the total world trade. Low-speed two-stroke diesel engines usually propel the largest trading ships. This engine type choice is mainly motivated by its high fuel efficiency and the capacity to burn cheap low-quality fuels. To reduce the marine freight impact on the environment, the International Maritime Organization (IMO) has introduced stricter limits on the engine pollutant emissions. One of these new restrictions, named Tier III, sets the maximum $\mathrm{NO}_{\mathrm{x}}$ emissions permitted. New emission reduction technologies have to be developed to fulfill the Tier III limits on two-stroke engines since adjusting the engine combustion alone is not sufficient. There are several promising technologies to achieve the required $\mathrm{NO}_{\mathrm{x}}$ reductions, Exhaust Gas Recirculation (EGR) is one of them. For automotive applications, EGR is a mature technology, and many of the research findings can be used directly in marine applications. However, there are some differences in marine two-stroke engines, which require further development to apply and control EGR.

The number of available engines for testing EGR controllers on ships and test beds is low due to the recent introduction of EGR. Hence, engine simulation models are a good alternative for developing controllers, and many different engine loading scenarios can be simulated without the high costs of running real engine tests. The primary focus of this thesis is the development and validation of models for two-stroke marine engines with EGR. The modeling follows a Mean Value Engine Model (MVEM) approach, which has a low computational complexity and permits faster than real-time simulations suitable for controller testing. A parameterization process that deals with the low measurement data availability, compared to the available data on automotive engines, is also investigated and described. As a result, the proposed model is parameterized to two different two-stroke engines showing a good agreement with the measurements in both stationary and dynamic conditions.

Several engine components have been developed. One of these is a new analytic in-cylinder pressure model that captures the influence of the injection and exhaust valve timings without increasing the simulation time. A new compressor model that can extrapolate to low speeds and pressure ratios in a physically sound way is also described. This compressor model is a requirement to be able to simulate low engine loads. Moreover, a novel parameterization algorithm is shown to handle well the model nonlinearities and to obtain a good model agreement with a large number of tested compressor maps. Furthermore, the engine model is complemented with dynamic models for ship and propeller to be able to simulate transient sailing scenarios, where good EGR controller performance is crucial. The model is used to identify the low load area as the most challenging for the controller performance, due to the slower engine air path dynamics. Further low load simulations indicate that sensor bias can be problematic and lead to an undesired black smoke formation, while errors in the parameters of the controller flow estimators are not as critical. This result is valuable because for a newly built engine a proper sensor setup is more straightforward to verify than to get the right parameters for the flow estimators. 


\section{Populärvetenskaplig sammanfattning}

I större delen av världen stiger konsumtionen av produkter varje år. Ofta tillverkas dessa produkter inte lokalt, utan måste transporteras långa avstånd för att nå sin slutdestination. Behovet av att förflytta gods täcks främst genom transporter till havs, med stora fraktfartyg som drivs av förbränningsmotorer. De större fraktfartygen drivs av tvåtaktsmotorer, vilka har flera grundläggande skillnader mot den typiska fyrtaktsmotorn som används i bilar. Tyvärr producerar dessa enorma förbränningsmotorer stora mängder skadliga utsläpp som förorenar miljön. Detta påverkar inte endast vår hälsa utan även den hos alla andra levande varelser bosatta på jorden. Därav är den slutgiltiga frågan: hur kan vi minska den negativa påverkan som förbränningsmotorer i stora fraktfartyg har på vår miljö? Internationella organisationer som ansvarar för att reglera transporter till havs har nyligen tagit tag i denna fråga genom att ytterligare minska mängden tillåtna skadliga utsläpp från fartygsmotorer. Detta görs med avsikten att få utvecklare och tillverkare av fartygsmotorer att sträva efter mer miljövänliga förbränningsmotorer, på samma sätt som det gjort för bilindustrin. Nuvarande tekniker för att minska föroreningar är välutvecklade för användning på bilmotorer, men för de större motorerna som används i fartyg är utvecklingen efter. Denna avhandling siktar på att minska detta gap genom att utveckla användbara verktyg för ingenjörer som utvecklar motorer med föroreningssänkande egenskaper. Det finns flera olika tekniker för att sänka mängden utsläppta föroreningar, denna avhandling fokuserar på Exhaust Gas Recirculation (EGR), vilket främst reducerar farliga utsläpp genom att låta en del av motorns avgaser pumpas tillbaka in i motorn för att förbrännas igen.

De framtagna verktygen består av matematiska simulationsmodeller av motorkomponenter, dessa kopplas ihop för att tillsammans forma en virtuell motor som kan användas med en vanlig dator. Därutöver kombineras motormodellen med en fullständig fartygsmodell, så att realistiska simuleringar av motorn beteende under fartygsmanövrar kan utföras. Möjligheten att kunna testa koncept på förhand via simuleringar är väldigt användbart för ingenjörer och är billigt i jämförelse med att testa direkt på stora fartygsmotorer som förbränner stora mängder dyrbart bränsle. De beskrivna modellerna i avhandlingen är justerade för att beskriva två olika fartygsmotorer med hjälp av riktig motormätdata. Modellerna visas stämma väl överens med motorkaraktäristiken vid olika last. Särskild uppmärksamhet har dock givits till att få extra hög noggrannheten hos modellen när motorn arbetar vid låg last. Motorn arbetar typiskt vid låg last när ett fartyg förflyttar sig nära en hamn. Hamnar och kustlinjer är nära befolkade områden där utsläppsgränser är hårdare, därför måste tekniker för att minska utsläpp fungera på topp i dessa områden. Ett originellt reglerkoncept som undviker bildning av sot när ett fartyg accelererar testas med den utvecklade simuleringsmodellen och användbara förbättringsförslag beskrivs. Som ett resultat kommer kunskapen given i denna avhandling skynda på arbetet hos andra ingenjörer med målet att utveckla miljövänligare motorer, för ett mindre skadligt transportsystem inom en nära framtid. 


\section{Acknowledgment}

At the start of my Ph.D. studies, writing a dissertation felt like a very distant goal. Now, thanks to the contribution of many people in very different ways, I have reached this objective. Therefore, it is time to thank appropriately everyone who has helped me during the process.

I would like to start by thanking Lars Nielsen for letting me join the division of Vehicular Systems to pursue a doctoral degree. My supervisor, Lars Eriksson, deserves my most sincere gratitude for guiding me through the tortuous path of the Ph.D. studies. I have always received excellent advice from him, and I believe that he has transmitted me at least some of his huge passion for automotive systems research. I would like to say a special thank you to Vaheed Nezhadali for being a great colleague and for many football evenings, to Kristoffer Lundahl for the friendly atmosphere at the L-building and the funny moments during trips (and planning trips), and to Martin Sivertsson for his endless discussions about practically any topic. Moreover, it has been a pleasure to work with Christofer Sundström, Andreas Thomasson, Kristoffer Ekberg, and Viktor Leek in different publications. I would also like to thank Pavel Anistratov, Jordi Loureiro and Robin Holmbom for proofreading parts of this thesis, and Victor Fors for helping me with the Swedish language in this dissertation. Finally, I am very thankful to all current and former colleagues at the division for creating a great working environment at the office and during teaching sessions, and for many enjoyable situations during "fika" breaks and conference trips.

The financial support from the European Union's Hercules 2 project, and from the Vinnova's Industry Excellence Center LINK-SIC is much appreciated. I would also like to express my gratitude to everyone at MAN Diesel \& Turbo involved with the project. Special thanks to Morten Vejlgaard-Laursen and Casper Hededal Svendsen for managing the project from the industrial side. It has also been a pleasure to collaborate with Guillem Alegret regarding marine engine modeling, and share with him many good dinners every occasion that I was in Copenhagen. Kræn Vodder Busk is also much appreciated for helping out every time that I asked for more engine data, and for his valuable input on modeling and control of marine two-stroke engines.

I would also like to thank all my lifelong friends for their genuine friendship. I have been far away from them during these years, but we have shared plenty of fun moments during every visit and trip back home. My very international friends in Sweden are also much appreciated for many enjoyable pub nights, and for all the beer brewing sessions. I am very thankful to my sisters for, among many other reasons, always being available to help me out and share some laughs, to my mother for convincing me that I could do anything, and to my father for teaching me many useful things and even more for showing interest in my publications. I cannot mention here the rest of my family, but I am very grateful to them for their love and support. Last but not least, I would like to thank Marta for being in my life. Her daily smile and love mean a lot to me.

Xavier Llamas

Linköping, January 2018 


\section{Contents}

1 Introduction $\quad 3$

1.1 Thesis Outline . . . . . . . . . . . . . . . 6

2 Marine Two-Stroke Diesel Engines $\quad 7$

2.1 Characteristics of Marine Two-Stroke Engines . . . . . . . . . . . . . 7

2.2 Turbocharging and Turbocharger Models . . . . . . . . . . . . . . 13

2.3 The Exhaust Gas Recirculation System . . . . . . . . . . . . . . . . . 14

2.4 Measurement Availability . . . . . . . . . . . . . . . . . . . . . 17

3 Publications and Main Contributions 21

3.1 Summary and Contributions of the Papers Included in the Thesis . . . 21

3.2 Other Publications by the Author . . . . . . . . . . . . 24

$\begin{array}{ll}\text { References } & 27\end{array}$

$\begin{array}{ll}\text { Papers } & 37\end{array}$

1 Parameterizing Compact and Extensible Compressor Models Using $\begin{array}{ll}\text { Orthogonal Distance Minimization } & 39\end{array}$

1 Introduction . . . . . . . . . . . . . . . . . . . . . 40

2 Compressor Maps . . . . . . . . . . . . . . . . . . 41

$3 \quad$ Experimental Data . . . . . . . . . . . . . . . . . . . . . 43

4 Compressor Model . . . . . . . . . . . . . . . . . . 43

5 Compressor Model Parametrization . . . . . . . . . . . . . . 50

6 Model Validation . . . . . . . . . . . . . . . . . . . 55

$7 \quad$ Conclusions . . . . . . . . . . . . . . . . . . . 58

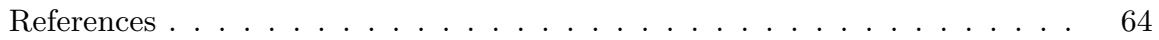

vii 
2 Control-Oriented Compressor Model with Adiabatic Efficiency Extrapolation

1 Introduction . . . . . . . . . . . . . . . . . . . . . . . . 69

2 Compressor Performance . . . . . . . . . . . . . . . . 70

$3 \quad$ Experimental Data . . . . . . . . . . . . . . . . . . . . . . . 73

4 Compressor Model . . . . . . . . . . . . . . . . . . . . . . . . . 74

5 Model Parameterization . . . . . . . . . . . . . . . . . . . 80

6 Model Validation . . . . . . . . . . . . . . . . . . . . . . . 86

$7 \quad$ Conclusions . . . . . . . . . . . . . . . . . . . . 93

References . . . . . . . . . . . . . . . . . . . 96

3 Modeling of a Large Marine Two-Stroke Diesel Engine with Cylinder $\begin{array}{lr}\text { Bypass Valve and EGR System } & 99\end{array}$

1 Introduction . . . . . . . . . . . . . . . . . . . . . . . 100

2 Modeling . . . . . . . . . . . . . . . . . . . . . . 100

$3 \quad$ Experimental data and tuning procedure . . . . . . . . . . . . . . . 107

4 Model Validation . . . . . . . . . . . . . . . . . . . . . . . . 109

5 Conclusions . . . . . . . . . . . . . . . . . . . 109

References . . . . . . . . . . . . . . . . . . . . . . 114

4 A Model of a Marine Two-Stroke Diesel Engine with EGR for Low $\begin{array}{ll}\text { Load Simulation } & \mathbf{1 1 7}\end{array}$

1 Introduction . . . . . . . . . . . . . . . . . . . . 118

2 Experimental data . . . . . . . . . . . . . . . . . . . . 119

3 Modeling . . . . . . . . . . . . . . . . . . . . . . . . . 119

4 Parameterization Procedure . . . . . . . . . . . . . . . . . 125

5 Model Validation . . . . . . . . . . . . . . . . . . . 126

6 Conclusions . . . . . . . . . . . . . . . . . . . 127

References . . . . . . . . . . . . . . . . . . . . 132

5 Control-Oriented Modeling of Two-Stroke Diesel Engines with EGR for Marine Applications $\quad 135$

1 Introduction . . . . . . . . . . . . . . . . . . . . . 137

2 Experimental Data . . . . . . . . . . . . . . . . . . . . 140

3 Engine Modeling . . . . . . . . . . . . . . . . . . . . . . . . 141

$4 \quad$ Model Parameterization . . . . . . . . . . . . . . . . . . . 158

5 Model Validation . . . . . . . . . . . . . . . . . . . . . . 161

6 Guidelines for Future Engine Measurements . . . . . . . . . . . . . . 166

7 Propeller and Ship Resistance Models . . . . . . . . . . . . . . . . . 166

8 Conclusions . . . . . . . . . . . . . . . . . . . . . 173

References . . . . . . . . . . . . . . . . . . . 179

6 Robustness Analysis of the Next Generation of EGR Controllers in Marine Two-Stroke Diesel Engines 183

1 Introduction . . . . . . . . . . . . . . . . . . . . 185

2 Engine and Ship Models . . . . . . . . . . . . . . . . . 186

3 Engine Controller . . . . . . . . . . . . . . . . . . . . . . 186

$4 \quad$ Results . . . . . . . . . . . . . . . . . . . . . 190

$5 \quad$ Conclusions . . . . . . . . . . . . . . . . . . . 195

References . . . . . . . . . . . . . . . . . . . . . 199 


\section{Introduction}





\section{Introduction}

The transportation sector is responsible for an enormous amount of energy consumption, which continues to grow every year. Despite the increase in renewable energy consumption seen in the last years, this sector is still overwhelmingly based on petroleum consumption, see U.S. Energy Information Administration [1]. Internal Combustion Engines (ICEs) of the reciprocating type, are used as prime movers in a wide variety of vehicle types, from small motorcycles to massive cargo ships. This kind of engines can use alternative fuels, but in general, they are consumers of petroleum-based fuels.

For the particular case of the largest marine vessels, like container ships and bulk carriers, the most common engine choice is the low-speed two-stroke diesel engine. One of the main reasons for this selection is the high fuel efficiency of this type of engine. However, two-stroke diesel engines are also responsible for a significant amount of pollutant emissions due to, among other reasons, the usual low-quality fuel that they burn.

The last decades have also seen an increased interest in reducing the environmental impact that the ICEs have on Earth's ecosystems. Governments and governmental institutions, following the scientific progress and societal demands, have gradually introduced more strict pollutant emission limits on the ICEs exhaust gases. These regulations have forced the engine manufacturers to invest in research for new technologies that mitigate the amount of different harmful pollutants produced, and thus, progressively reduce the impact that the ICEs have on our environment.

\section{Emission Regulations on Marine Engines}

The International Maritime Organization (IMO) is the United Nations agency responsible for setting the emission limits in the marine freight sector. While 
road vehicles have been at the vanguard of emission reduction regulations, the maritime transport started to be regulated several years later. For the case of nitrogen oxides $\left(\mathrm{NO}_{\mathrm{x}}\right)$ emissions, the first limitation was named Tier I and it was introduced in the year 2000. More recently, the stricter Tier III emission limits have been introduced [2], and constitute an essential step towards a more environmentally friendly maritime transport. Tier III limits only apply to specific $\mathrm{NO}_{\mathrm{x}}$ Emission Control Areas (NECAs). Outside the NECAs, sailing ships have to respect the less strict Tier II $\mathrm{NO}_{\mathrm{x}}$ emission limits. Currently, the North American, Puerto Rico and Hawaii coasts are NECAs, and it is important to mention that the restrictions are applied only to vessels built on or after the 1st of January 2016. Recently, the North Sea and the Baltic Sea have been formally designated NECAs by IMO [3], and the Tier III $\mathrm{NO}_{\mathrm{x}}$ limits will have to be fulfilled by vessels constructed on or after the 1st of January 2021.

IMO also regulates sulfur oxides $\left(\mathrm{SO}_{\mathrm{x}}\right)$ and particulate matter $(\mathrm{PM})$, which apply to all vessels regardless of the construction date. Similar to the $\mathrm{NO}_{\mathrm{x}}$ case, more strict limits are defined in particular $\mathrm{SO}_{\mathrm{x}}$ Emission Control Areas (SECAs), and currently, the NECAs mentioned above are also SECAs, see IMO [4] for further details. Furthermore, IMO has also envisioned an important reduction of carbon dioxide $\left(\mathrm{CO}_{2}\right)$ emissions from the international shipping. This path has started by enforcing mandatory increases of engine efficiency through the Energy Efficiency Design Index (EEDI) introduced in 2013, see IMO [5].

\section{Emission Abatement Technologies for Marine Engines}

In marine two-stroke engines, sulfur oxide limits are usually fulfilled by using a better quality heavy fuel oil with less sulfur content, or with the help of scrubbers to clean the exhaust gases from $\mathrm{SO}_{\mathrm{x}}$. For the case of particulate matter, also better quality fuel, scrubbers and diesel particulate filters are suitable solutions, see Lack et al. [6].

Reaching the stricter $\mathrm{NO}_{\mathrm{x}}$ Tier III emission limits on marine two-stroke engines is a more complicated task. Decreasing the $\mathrm{NO}_{\mathrm{x}}$ emissions can be achieved by adjusting the combustion process using different fuel injection timings or pilot injections, see Andreadis et al. [7], Liu et al. [8], and Hountalas et al. [9]. Miller timing is also a suitable technique to reduce $\mathrm{NO}_{\mathrm{x}}$ at a price of an increased specific fuel oil consumption (SFOC), as discussed in Feng et al. [10]. Moreover, water addition techniques have an even more significant potential to reach the Tier III limits, but they are associated with substantial increases on soot emissions and SFOC, see Henningsen [11], Tanner et al. [12], and Chryssakis et al. [13]. As a result, more complex technologies have to be adopted by marine ICE designers since the techniques mentioned above are not sufficient to reach the Tier III target alone. One of the possibilities is to design engines capable of running on gas or dual-fuels, see Ott et al. [14] and Unseki [15]. Other two promising technologies considered by the engine designers to achieve such reduction are the Selective Catalytic Reduction (SCR) and the Exhaust Gas Recirculation (EGR). The different $\mathrm{NO}_{\mathrm{x}}$ abatement technologies have distinct advantages and disadvantages, and currently, there is no clear trend of which one will dominate the market in the future. 
SCR is based on an after-treatment chemical process that removes the formed $\mathrm{NO}_{\mathrm{x}}$ by injecting a reacting agent in the catalytic converter. There are two primary SCR architectures: high pressure and low pressure, depending on the position of the SCR reactor relative to the engine's turbine, e.g., Sandelin and Peitz [16] and Ryu et al. [17].

On the other hand, EGR is a technology that aims at reducing the amount of formed $\mathrm{NO}_{\mathrm{x}}$ during the combustion. This reduction is achieved by increasing the heat capacity of the gas in the combustion chamber by diluting the air with recirculated burned gases, which also lowers the $\mathrm{O}_{2}$ availability. With a higher heat capacity, the cylinder temperatures are lower which directly reduces the amount of thermal $\mathrm{NO}_{\mathrm{x}}$ production, Heywood [18]. Furthermore, EGR can be combined with injection control strategies, water injection and Miller timing to adjust even more the trade-offs between $\mathrm{SFOC}$, soot formation, and $\mathrm{NO}_{\mathrm{x}}$ emissions, e.g., Feng et al. [10], Liu et al. [19], Wang et al. [20], and Sun et al. [21]. It is important to recall that the highest $\mathrm{NO}_{\mathrm{x}}$ decrease has to be achieved in the coastal NECAs where certain harbors are located. This issue complicates the EGR control problem since the ship has to be able to maneuver at low engine loads while keeping a high EGR rate. Therefore, extending the simulation models to low load operation is crucial for using them to design and test better controllers.

\section{Thesis Motivation}

EGR systems on low-speed two-stroke diesel engines are relatively new. By reducing the oxygen concentration of the fresh air used in the combustion, the produced $\mathrm{NO}_{\mathrm{x}}$ can be reduced substantially. See the following test results for a low-pressure EGR: Okabe et al. [22] and Hiraoka et al. [23]. Controlling a specified oxygen level setpoint is a relatively simple task by using feedback control during slow transients. However, the feedback controller has a poor performance during fast transients. This bad performance is mainly due to the inherent delays in the scavenging oxygen sensor signal, together with the direct coupling between oxygen concentration and maximum fuel burning capacity during accelerations, see Nielsen [24]. Thus, more advanced control algorithms are necessary to avoid undesirable black smoke from incomplete combustion, as proposed in Nielsen et al. [25, 26].

During the investigation and practical implementation of more advanced control strategies, engine testing time is needed, which is not an abundant resource. The first reason is that there are not many EGR engines available yet, and testing them requires agreements with the engine owners. Test beds exist, but not in as large numbers as in the automotive industry. So the overall availability is very limited, and the high cost of running these engines is also a motive for finding alternatives. Hence, having an accurate and fast simulation model that can be used for controller design and evaluation is a great asset to speed up the development, and also to save money by doing only the minimum amount of real engine tests.

The work presented in this thesis is dedicated to the development, parameterization, and validation of low-speed two-stroke engine models for EGR 
control applications. The model has been applied to two different two-stroke diesel engines with EGR, showing its generality. Several engine components are investigated in more detail, in particular, a compressor model capable of extrapolating to low speeds, which is a requirement to be able to simulate low load operation with the engine model. Furthermore, a dynamic model of the ship surge movement is included to be able to simulate ship sailing scenarios. The ship simulation platform has been used to test the next generation of EGR controllers, to demonstrate the usefulness and applicability of the developed models. The results identify the low load area as the most challenging for the EGR controller performance due to the engine slower air path dynamics. The results also show that sensor bias in the EGR controller inputs could lead to black smoke formation while errors in the parameters of controller flow estimators are not as problematic. This work has been carried out in collaboration with MAN Diesel \& Turbo, based in Copenhagen, and under the financial support of the Hercules-2 European project [27]. Part of the work has been co-funded by the Vinnova's Industry Excellence Center LINK-SIC [28].

\subsection{Thesis Outline}

The next chapter is dedicated to introducing the particularities of the marine low-speed two-stroke engines studied in this thesis. Further details about the turbochargers, the EGR system, and the available measurements on those engines are also discussed with the purpose to serve as an introduction to the papers. The main contributions to the research field of the papers that constitute this thesis are summarized in the third chapter. Moreover, this third chapter also contains other publications by the author during this period, mentioning the author's particular contributions in each of them. All the modeling details and specific contributions are included in the six appended papers. The appended papers are often referenced in Chapter 2 using its order number, which can be consulted in Section 3.1. 


\section{Marine Two-Stroke Diesel Engines}

This chapter is intended to give a brief introduction to the main characteristics of large marine two-stroke diesel engines used nowadays in ship propulsion. This chapter also covers turbocharging and EGR systems applied to this kind of engine. Finally, the chapter includes a description of the type of measurements available for development of the thesis models, with focus on the limitations and differences that exist compared to the kind of measurements available on smaller automotive-size engines.

\subsection{Characteristics of Marine Two-Stroke En- gines}

Low-speed two-stroke diesel engines are the preferred engine type for propulsion of large merchant ships. For instance, container ships, oil and gas tankers and bulk carriers are usually propelled by large two-stroke engines. This choice is a consequence of several important factors, as described in Xiros [29], and Woodyard [30]. First, these engines have a high thermal efficiency, with numbers reaching approximately $50 \%$. Waste heat recovery systems can be installed in the engine to obtain even higher efficiencies from the hot exhaust gases, see Shu et al. [31]. Moreover, they are capable of burning cheap low-quality fuels like heavy fuel oil. Two-stroke engines operate at low-speeds and are capable of reversing its rotation, which avoids the need of gearboxes by connecting the engine shaft directly to the propeller. Furthermore, they are simpler, more reliable and have a higher power to weight ratio compared to four-stroke engines.

Nowadays, only three engine designers remain in the low-speed two-stroke engine business: MAN Diesel \& Turbo, Mitsubishi Heavy Industries, and Winterthur Gas \& Diesel. The three of them design low-speed two-stroke engines 


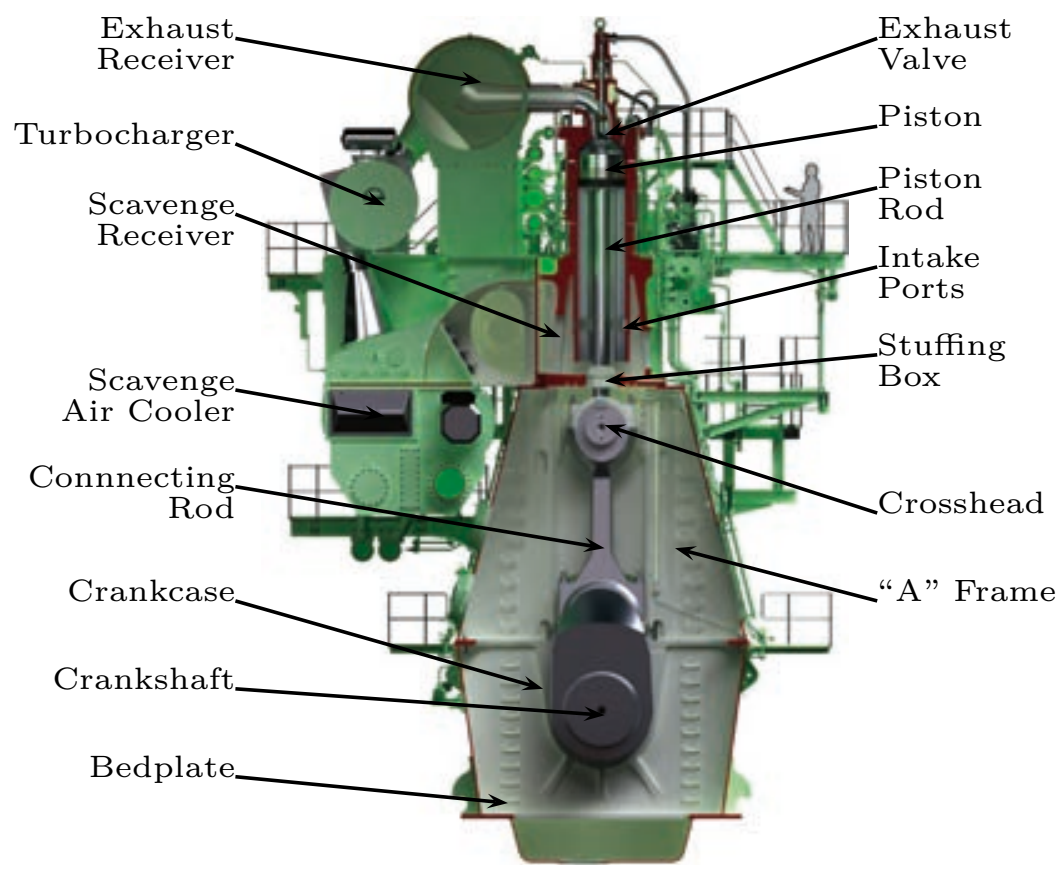

Figure 2.1: Cross section of a MAN Diesel \& Turbo G95ME-C engine with indications of the main engine components. The engine size can be estimated with the help of the human drawing included. (The original picture belongs to MAN Diesel \& Turbo, it is edited and reproduced here with permission.)

following similar principles: crosshead, constant pressure turbocharged and uniflow scavenged with a single exhaust valve in the cylinder head, see Woodyard [30] for more details. Figure 2.1 contains an annotated picture of one such engine with indications of the main engine components. An important characteristic is that the piston and the scavenging receiver are separated from the crankcase by the stuffing box. This separation prevents the crankcase and cylinder oils from mixing, which is undesirable due to the sulfur products from the combustion usually present in the cylinder oil. The crosshead pin that joins the piston and connecting rods travels inside the vertical crosshead guides mounted in the "A" frame. These guides ensure the alignment of the piston with the cylinder liner and absorb any side forces from the crankshaft. Moreover, it allows the use of very long strokes, which improve overall ship efficiency by reducing, even more, the engine speeds for the same power output, see Woodyard [30]. Figure 2.1 also shows the bedplate of the engine, which is the rigid structure that supports the crankshaft and the rest of the engine components.

Large crosshead two-stroke engines are available in a variety of sizes, speeds, and power outputs. Before the introduction of the IMO EEDI index to reduce $\mathrm{CO}_{2}$ emissions, these engines used to be bigger, but nowadays there is a trend for downsizing. The piston bores are in the range of 300 to $950 \mathrm{~mm}$, and strokes from 1.3 to $3.7 \mathrm{~m}$. The number of engine cylinders is between 5 to 12 , 
depending on the configuration. The maximum continuous rating (MCR) speeds are between 60 to 250 revolutions per minute, with corresponding power outputs in the range from $2000 \mathrm{~kW}$ to $82 \mathrm{MW}$. See Winterthur Gas \& Diesel [32], MAN Diesel \& Turbo [33], and Mitsubishi Heavy Industries [34] for examples of specific two-stroke engine designs.

\subsubsection{The Two-Stroke Cycle}

The two-stroke cycle has some notable differences compared to the four-stroke cycle widely used in automotive combustion engines. The most important difference is that the complete thermodynamic cycle is performed with only one crankshaft revolution compared to the two revolutions required for the fourstroke engines. This shorter cycle implies that the cylinders fire each revolution, which theoretically means that they can provide two times more power than a four-stroke engine of the same size, see Heywood [18]. On the other hand, the cylinder gas exchange process has to be done within this single revolution. The crosshead engines rely on the efficient uniflow scavenging method to remove the burned gases from the cylinder and fill it with fresh air from the scavenging box, see Blair [35], Heywood and Sher [36], and Woodyard [30] for more details. Uniflow engines have a single exhaust valve per cylinder, which is mounted in the center of the cylinder head. For the modern electronically controlled engines, the exhaust valve opening and closing angles can be freely chosen by the control system, which introduces flexibility to control the desired cylinder pressure.

Figure 2.2 shows a diagram of the two-stroke cycle with the main events. The intake port opening and closing (IPO and IPC respectively) angles are geometrically fixed based on the piston movement. As discussed previously, the exhaust valve opening and closing angles (EVO and EVC respectively) are determined by the control system and change depending on the engine load and operating mode. The angle where the fuel injection starts $\left(\alpha_{i n j}\right)$ is also variable, and it is used to control the combustion phase.

Figure 2.3 shows an example of the measured cylinder pressure plotted against the corresponding cylinder volume. The cylinder compression pressure $p_{c y l, c o m p}$ depends strongly on the exhaust valve closing since it defines the start of the compression process. For a fixed fuel mass, the maximum cylinder pressure $\left(p_{c y l, \max }\right)$ is influenced by the fuel injection starting angle and the current cylinder pressure at that angle. The exhaust valve opening has a direct effect on the power produced by the cylinders since it defines the expansion phase duration. Moreover, it also affects the outlet gas temperature. Both opening and closing angles of the exhaust valve have a significant influence on the cylinder scavenging process.

In the recent years, many authors have investigated two-stroke cylinder pressure models, due to the need to research new technologies to reduce the emissions of these engines. Investigations of the $\mathrm{NO}_{\mathrm{x}}$ reduction potential with EGR dilution have been performed with zero-dimensional models, e.g., Scappin et al. [37], or with more complex multi-zone models, see Hountalas et al. [9], and Raptotasios et al. [38]. More time consuming Computational Fluid Dynamics (CFD) codes of the cylinder and the combustion chamber have been used to in- 


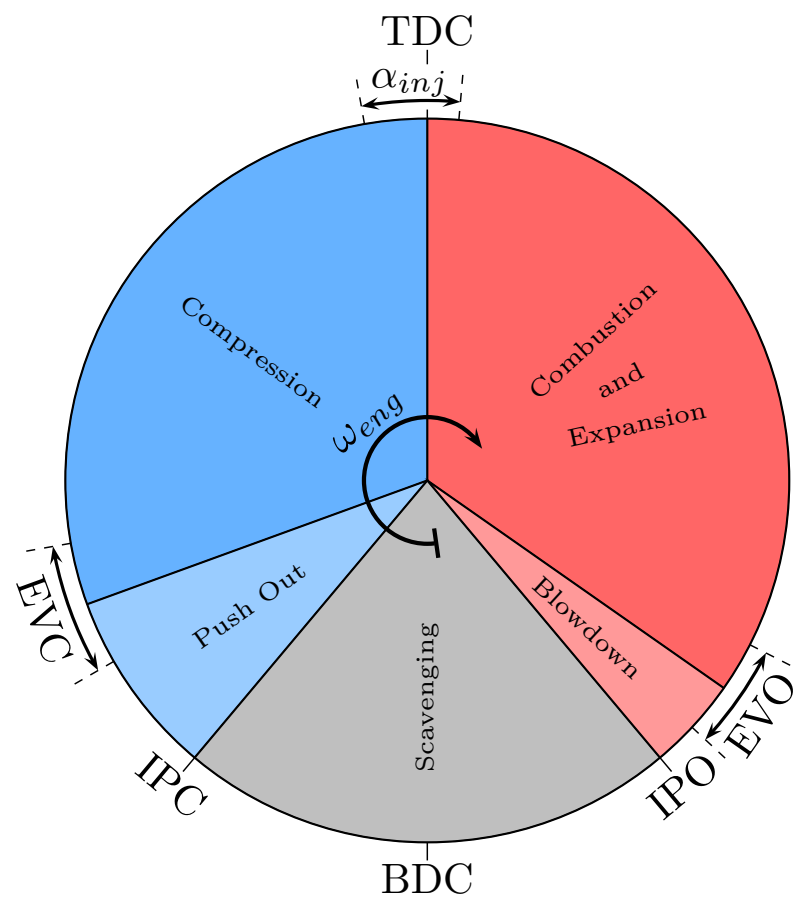

Figure 2.2: Uniflow two-stroke engine timing diagram. The principal cylinder events and phase names are depicted, together with the forward rotation of the engine. The upper and lower points correspond to the piston top and bottom dead center (TDC and BDC respectively). 


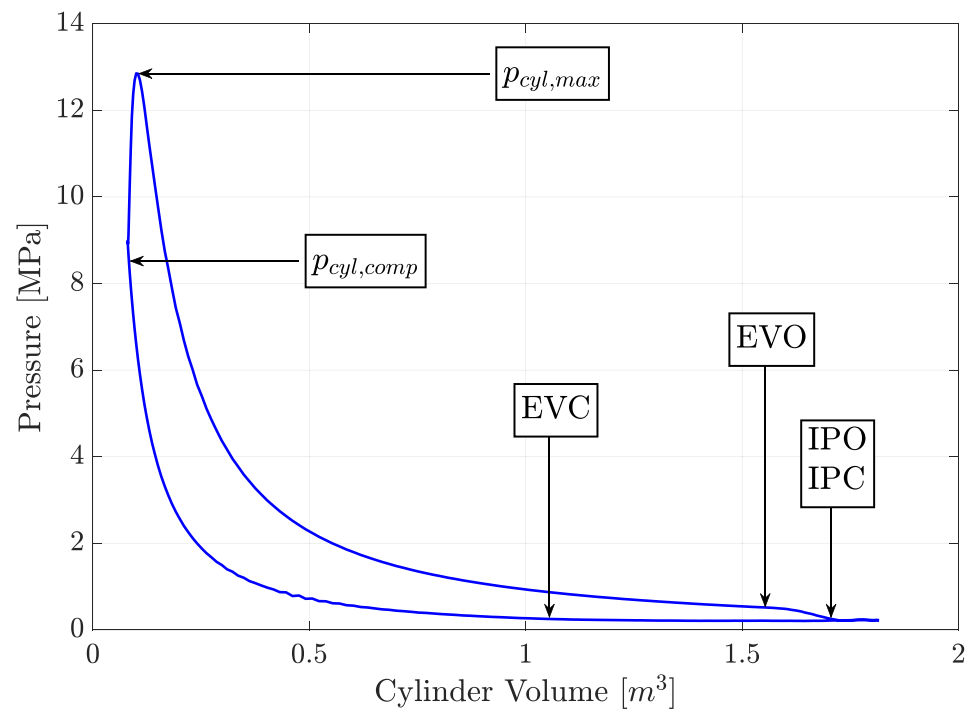

Figure 2.3: Pressure vs. volume diagram of a low-speed marine two-stroke engine. Approximate corresponding volumes where the intake ports and the exhaust valve open and close are depicted in the diagram. The diagram also indicates the maximum cylinder pressure and the cylinder pressure after the compression process.

vestigate several combustion related issues. Potential $\mathrm{NO}_{\mathrm{x}}$ reductions depending on EGR rate and injection timing are analyzed in Sun et al. [21], and Wang et al. [20]. Other examples of investigated topics with CFD models are heavy fuel oil evaporation in Stamoudis et al. [39], the impact of alternative fuels on the combustion and emission products in Sun et al. [40], and sensitivity analysis of different fuel characteristics and operating conditions on the combustion in Zhou et al. [41]. A computationally faster approach is taken in Sui et al. [42], using a Seiliger cycle to model the in-cylinder pressure of a medium speed marine diesel engine. Paper 5 [43] of the thesis contributes with an algebraic in-cylinder pressure model that captures the effects of the ordered exhaust valve and fuel injection angles on the cylinder pressure. Cylinder pressure measurements are used to validate the proposed analytic model based on an adaptation of the work described in Eriksson and Andersson [44], from automotive four-stroke engines to marine two-stroke applications. Furthermore, the proposed approach models the thermodynamic gas properties as a function of the temperature and the gas composition, which is identified as an important factor in Murphy et al. [45] for accurate temperature prediction in marine applications.

Accurate modeling of the uniflow engine scavenging process is also important when developing cylinder pressure models. The simpler single-zone models with single or multiple phases can be a good start and are suitable for MVEM approaches. Examples can be found in Merker and Gerstle [46], and Heywood and Sher [36], where different models for different scavenging architectures are 
gathered. A collection of more complex multi-zone models is also included in $[46,36]$. If a deeper analysis is required, CFD models are the usual choice due to the complicated flow interactions involved. Some examples of scavenging CFD studies are Haider [47], Sigurdsson et al. [48], and Lamas and Vidal [49]. CFD results can be used to validate and develop simpler algebraic models. This strategy is carried out in Andersen [50], where an algebraic model is proposed for modeling the scavenging process of a crosshead uniflow engine. Algebraic models are well suited for control application models since they have low computational requirements. Hence, the original model from Andersen [50] is used in Paper 5 [43] of the thesis, but the model is adapted to a larger engine than the one studied in the original publication.

\subsubsection{Models of Marine Two-Stroke Diesel Engines}

Modeling of marine crosshead two-stroke engines has not received the same attention in the research literature as the case of automotive four-stroke engines. Nevertheless, several authors have studied different modeling strategies for this type of engine. With the purpose of improving the engine governor design, two-stroke engine models started to be developed at the beginning of 1980's. In Woodward and Latorre [51], a complete two-stroke model that captures the transient behavior of the engine is described in detail. The importance of the turbocharger dynamics for the transient response of the engine shaft speed is investigated in Blanke and Anderson [52]. Further investigations of the significance of the turbocharger dynamics are carried out in Hendricks [53]. This latter paper introduced the mean value engine model (MVEM) terminology, which refers to models with averaged signals over one or several engine cycles, see Eriksson and Nielsen [54] and Guzzella and Onder [55].

Further development of two-stroke MVEMs is done in Theotokatos [56], where two different MVEM approaches are shown to give good stationary and dynamic results compared with a more accurate crank angle based zero-dimensional model of the engine. Engine control development has been supported with the previous mentioned two-stroke MVEM, e.g., Xiros and Theotokatos [57]. The low load operation of the engine is studied in Guan et al. [58], with a dedicated compressor model for low load simulation integrated into a two-stroke MVEM. In Theotokatos and Tzelepis [59], the MVEM is integrated with a complete ship model which is used to investigate performance and emissions under different loading scenarios. Furthermore, other authors have also investigated the use and accuracy of MVEM for two-stroke engines. Some examples are Karlsen [60], Tian et al. [61], and Zhu [62]. A simpler approach than an MVEM is to use black-box modeling based on dynamic transfer functions, as proposed in Xiros [29].

More accurate and computationally demanding zero-dimensional models of the cylinder processes have also been used in the development of complete two-stroke engine models. This kind of models have a crank angle resolved formulation of the in-cylinder processes, and thus are capable of including more complex modeling of the combustion and the scavenging processes. In Kyrtatos et al. [63, 64], such model is validated and shown to reproduce accurately 
the measurements taken on board of a container ship. The modeling papers mentioned above are developed with the general thermodynamics code described in Kyrtatos [65]. Another example of the usage of this engine thermodynamics code is shown in Livanos et al. [66], where it is used to model and simulate a large two-stroke diesel engine during a fire in the scavenging receiver. More recent work is carried out in Guan et al. [67], where a previous MVEM model is extended with a zero-dimensional combustion model and used to investigate the effects of turbocharger cut-out and auxiliary blower activation. The same zero-dimensional model is used in Theotokatos et al. [68] to map different engine parameters and use the results to develop functional extensions to a two-stroke diesel MVEM. The fundamental purpose of this is to obtain a fast execution time MVEM that captures the effects of changes in the combustion input signals, e.g., fuel injection start. In Yum et al. [69], a complete ship propulsion system with a crank angle based cylinder model is used to investigate the effect of sea waves on the engine operation. Another interesting approach is presented in Mavrelos and Theotokatos [70, 71], where the commercial software GT-power is used to model a dual-fuel two-stroke engine. Finally, a distinct method is described in Tang et al. [72], where the zero-dimensional cylinder model and the rest of the MVEM are integrated based on asynchronous calculations to achieve a real-time simulation model.

Complete control-oriented two-stroke diesel engine models capable of simulating EGR are a relatively new topic in the research literature. Hence, the main contributions of this thesis concerning the general two-stroke engine modeling work are to incorporate many of the modeling ideas into new models capable of simulating EGR operation. More information about the thesis specific contributions in the field of marine EGR modeling is included in Section 2.3.

\subsection{Turbocharging and Turbocharger Models}

One critical drawback of the two-stroke engine is that it is neither a self-aspirating nor a self-exhausting engine, see Watson and Janota [73]. On the contrary, the dedicated intake and exhaust strokes in the four-stroke cycle ensure that, by the piston movement, the burned charge is expelled and the fresh gas is introduced into the cylinders. For the scavenging process to work on two-stroke engines, the scavenging receiver requires air at pressures above the atmospheric level. This pressure rise can be achieved by several technical solutions like supercharging or using the crankcase and the piston movement. However, the usual approach for crosshead two-stroke engines is to use one or several turbocharger units, together with auxiliary blowers to ensure that there is enough pressure for the scavenging process at low loads where the turbocharger efficiency usually drops. The auxiliary blowers are operated at a constant speed using electric motors and started or stopped depending on the current measured scavenging pressure.

Another benefit of turbocharging is that it increases the power output of a given engine. This increase is a consequence of a higher fuel burning capacity due to more mass of fresh air trapped in the cylinders at higher pressures. This power increase provided by the compressor side of the turbocharger is powered 
using a turbine that extracts the energy available from the hot pressurized exhaust gases. Careful matching of the turbocharger to the designed engine is crucial to ensure a positive pressure difference between scavenging and exhaust receivers, see Meier [74]. Otherwise during the period when the intake ports and the exhaust valve are simultaneously open, see Figure 2.2, issues with too much scavenging flow or even undesired burned gases flowing back to the scavenge receiver might occur. This positive pressure difference between scavenging and exhaust receivers has practical implications for the design of the EGR system as will be discussed in the following section.

Turbines on two-stroke engine turbochargers can be either radial or axial machines, depending on the power output and the required size of the turbocharger. The axial turbines are better solutions for the largest turbochargers due to higher operating efficiency and a less complicated manufacturing process, see Watson and Janota [73]. Suitable zero-dimensional models that can represent well the measured turbine maps of axial and radial turbines can be found in Serrano et al. [75], Stricker et al. [76], Sidorow et al. [77], and Eriksson [78] among others.

Radial compressors with vaned diffusers are usually the preferred choice for low-speed two-stroke engine turbochargers. Radial compressors have a wide operating range in mass flow values, and the vaned diffuser helps in providing higher efficiencies and pressure ratios, see Watson and Janota [73] for more details. The left side of Figure 2.4 contains a measured compressor map of a typical vaned radial compressor used for charging this kind of engines. The measured lowest speed line corresponds to approximately $44 \%$ of the maximum allowed compressor speed, and there are no measurements available for pressure ratios between 1 and 1.4. This lack of low-speed measurements is common in compressor performance maps. This unmeasured area introduces limitations on the complete turbocharged two-stroke simulation models since, at low loads, the compressor is usually operating outside of the measured area, see Figures 2 and 3 from Paper 4 [79] of this thesis for a graphical illustration. Hence, models that can extrapolate the compressor performance at low-speeds are required, as identified in Guan et al. [58], and Mizythras et al. [80], where a compressor model extrapolation method is described. Papers 1 and $2[81,82]$ are dedicated to the development of an extrapolation capable compressor model for both mass flow and efficiency prediction. The proposed model is based on previous work developed by Leufvén and Eriksson [83] and Martin et al. [84], which is further extended in this thesis together with a dedicated parameterization method. The right side of Figure 2.4 contains the proposed compressor model parameterized to the left map, as can be seen, the operating area of the model is broader and includes the desired low load performance.

\subsection{The Exhaust Gas Recirculation System}

EGR is a mature technology for reducing $\mathrm{NO}_{\mathrm{x}}$ on automotive four-stroke engines. Different EGR architectures exist; there are high and low-pressure systems, with and without cooling devices that have distinct advantages and disadvantages, see Eriksson and Nielsen [54]. In four-stroke engines, a valve usually controls the 

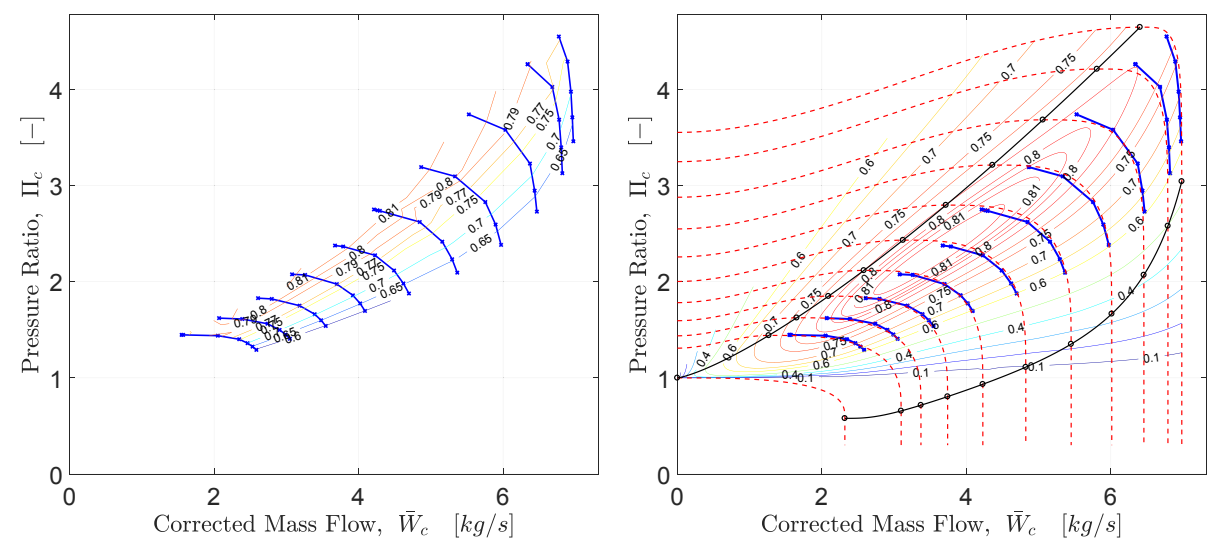

Figure 2.4: Left: Measured compressor map speed lines in the pressure ratio vs. corrected mass flow plane in blue crosses connected with solid blue lines. The measured efficiency is plotted as contour lines. Right: Modeled compressor in dashed red lines together with the modeled efficiency as contour lines. The measured speed lines are depicted as blue crosses connected with solid blue lines.

EGR flow, provided that there is sufficient pressure difference for the gas to flow from the exhaust to the intake manifold. In some cases, a Variable Geometry Turbine (VGT) is included, which enables new ways to control the EGR flow by actuating the turbine vanes. These vanes can influence directly the exhaust pressure as well as indirectly the intake pressure of the engine. For example, the interesting and complex EGR-VGT control problem on a four-stroke heavy-duty diesel engine is treated in Wahlström et al. [85].

EGR systems on low-speed two-stroke diesel engines are much more recent. For instance, a high-pressure EGR system was first installed on the test engine at the Diesel Research Centre in Copenhagen in 2009, see Nielsen [24]. Since then, more EGR systems have been installed on newly built ships, and more EGR engines are currently under construction to fulfill the IMO Tier III emission limits. MAN Diesel \& Turbo has adopted a high-pressure EGR solution, see Kaltoft and Preem [86], which is the modeled approach in this thesis, but low-pressure architectures have also been tested successfully by other engine designers, e.g., Hiraoka et al. [23].

Low-speed two-stroke engines have additional challenges compared to fourstroke engines when designing EGR systems. Due to the sulfur content of the heavy fuel oil used in the engine, the burned gases have to be cleaned of corrosive components before reintroducing them into the cylinders. Moreover, due to the essential positive pressure difference between scavenging and exhaust receivers described in the previous section, the EGR flow has to be mechanically forced. Thus, the desired mass flow is achieved using a blower, which increases the system complexity compared to the valve system used in four-stroke engines. These blowers are radial compressors, controlled using the speed of the electric motors used to drive them. A diagram of the MAN Diesel \& Turbo high-pressure EGR system applied to an engine is shown in Figure 2.5. As can be seen, the 


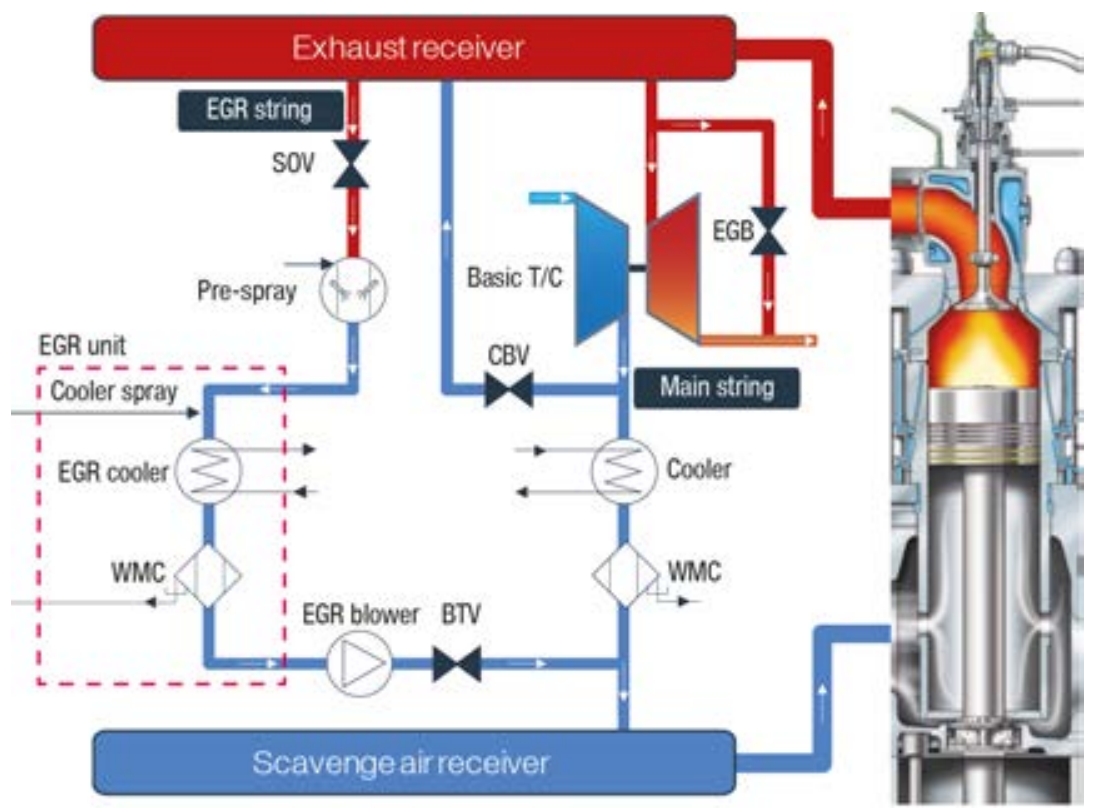

Figure 2.5: Diagram of the engine with a high-pressure EGR system gas path from MAN Diesel \& Turbo. The EGR flow is cleaned (water sprays) and cooled before being pumped to the scavenging pressure by the EGR blower. The Water Mist Catcher (WMC) ensures that the condensed water in the gas is removed. The Exhaust Gas Bypass (EGB) valve and Cylinder Bypass Valve (CBV) shown in the diagram are used to match the turbocharger $(\mathrm{T} / \mathrm{C})$ operation at different loads with and without EGR operation. The picture is reproduced from [87] with permission from MAN Diesel \& Turbo.

EGR string takes burned gases from the exhaust receiver. The gas flow is then cleaned and cooled before being pressurized and mixed with the fresh air going to the scavenge air receiver. For bigger engines, a similar configuration but with parallel turbochargers is used, more details can be found in MAN Diesel \& Turbo [87].

Due to its recent introduction, the research literature does not contain much modeling work of two-stroke engines with EGR. However, some ideas from the abundant four-stroke EGR modeling and control literature can be used when modeling EGR systems for low-speed two-stroke engines. This strategy is followed in the modeling work from Hansen et al. [88], where some of the modeling ideas developed for automotive four-stroke engines in Wahlström and Eriksson [89] are adapted to the two-stroke case. Further modeling work is carried out in Nielsen et al. [26], where the model described in Paper 3 [90] of this thesis is modified to work with molar flows and adapted to another engine. Moreover, in the same publication, several simplifications are done to the original MVEM to obtain a dynamically simplified model that is shown to capture the oxygen dynamics well. More recently, a one-dimensional model of a two-stroke 
EGR engine implemented in the commercial software GT-power was used to investigate EGR operation with exhaust gas bypass (EGB), and cylinder bypass (CB), see Wang et al. [91, 92]. Furthermore, a waste heat recovery system to extract energy from the hot EGR gas is modeled and optimized in Kyriakidis et al. [93].

The main purpose of this thesis is to develop and validate a control-oriented modeling approach for marine two-stroke engines with EGR, for low to high engine loads and different operating modes. Its primary application is to assist in the development of EGR controllers during transient operation. To the author knowledge, this kind of model has not been investigated in the research literature. Paper 3 [90], started this task, and presented a model for medium to high load simulations. Paper 4 [79] extends the load range to low loads by including the auxiliary blower and a compressor model capable of extrapolating to low speeds. The compressor model is described in Papers 1 and 2 [81, 82]. A more detailed MVEM is introduced in Paper 5 [43], where the generality of the model approach is shown by modeling another engine with EGR. The MVEM from Paper 5 proposes improvements on several components and includes models for the propeller and the ship surge dynamics to have a complete ship propulsion model. One of the possible applications is shown in Paper 6, where the model is used to analyze the performance and robustness during acceleration scenarios of the adaptive EGR controller described in Nielsen et al. [25, 26].

\subsection{Measurement Availability}

Measurement data of the engine at different operating points is required to develop, parameterize and validate models. In automotive engines, stationary data is typically collected in engine test beds by measuring different combinations of the engine control inputs. For instance, the torque-speed operating region of a diesel engine is usually gridded to collect a range from one to several hundred different operating points, this set of measurements is usually called "engine map". This large quantity of data is valuable to develop and parameterize models that can work in a broad operating region of the engine. For the case of marine two-stroke engines, the number of measurements has to be drastically reduced due to the longer stabilization time and the high fuel costs of running these engines. Moreover, the lower test bed availability compared to the automotive industry is also an issue, and performing measurements has to be extensively planned.

When the manufacturing process of a new engine is finalized, its performance is tested and recorded during the shop test to ensure that it works well and it is capable of delivering the designed power output. This set of measurements usually contains less than ten different stationary points. For the case of EGR engines, about the double of points are taken since the engine has more operating modes with EGR enabled. Moreover, the lowest measured load point is usually $25 \%$ of the maximum engine load, which is a higher load value than the usual engine loads during harbor maneuvering. These unmeasured loads make the shop test data unsuitable for developing the low load capable engine model. 
Hence, the continuous data recordings of the engine sensors provided by MAN Diesel \& Turbo have been used to identify stationary operating points off-line by post-processing the data. This approach results in a higher number of available stationary points with a wider load span, and also includes necessary measurements that were unavailable in the shop test data, e.g., the injection angle.

For the case of Paper 5 [43], the data sources are the continuous recordings of the installed sensors on the ship engine during normal sailing operation. Figure 2.6 shows an example of several measured signals from the sailing vessel with an identified stationary point highlighted. Sailing measurements of approximately ten months were used to find as many different operating points as possible of the modeled engine. In Papers 3 and 4 [90, 79], the model is based on the Diesel Research Center test engine, and a similar approach is followed to obtain stationary data. However, collecting data from the same engine layout is more difficult since very often this test engine is rebuilt to change and test new engine components, e.g., turbochargers or EGR blowers. Moreover, the continuous sensor recordings correspond to experiments done for other projects and purposes, so the data was reused.

During the parameterization of MVEMs for automotive engines, the usual strategy is to start with the stationary data to estimate the stationary outputs of the different engine component models separately. See Guzzella and Onder [55], and Eriksson and Nielsen [54] for more information about the parameterization and measurement process, and Wahlström and Eriksson [89] for an application example. This strategy helps in dealing with the model large number of unknown parameters. However, air mass flow has to be measured, which is a complicated measurement in large marine two-stroke engines and it has not been possible to measure during this project. Hence, the stationary parameterization of the marine engine model has to be done at once, which increases its complexity substantially. In Paper 5 [43] of this thesis, a different approach to obtain an estimate of the air mass flow when EGR is disabled is described, using the compressor model from Papers 1 and 2 [81, 82]. This method simplifies the parameterization process but requires measurements of turbocharger speed, compressor inlet temperature and pressure, and compressor outlet pressure.

Dynamic data is also required to parameterize and validate the models under transient operation, see Guzzella and Onder [55], Eriksson and Nielsen [54], and Wahlström and Eriksson [89]. When the data comes from normal ship sailing operation, most of the time the engine is at constant load without many transients. However, there are still interesting load steps or input signal changes that can be used. For instance, between 1000 and 1600 seconds in the dataset shown in Figure 2.6. This kind of dynamic data is extracted from the available measurements and used in the estimation and validation of the engine models.

To sum up, obtaining a wide range of measured operating points from marine two-stroke diesel engines is often complicated. Nevertheless, the proposed MVEM can still be parameterized and validated with the available data as shown in Papers 3,4 and $5[90,79,43]$ of the thesis. Paper 5 [43], also contains guidelines of important signals to be included in the engine shop test measurements, with the purpose to simplify the parameterization procedure. Furthermore, if only 

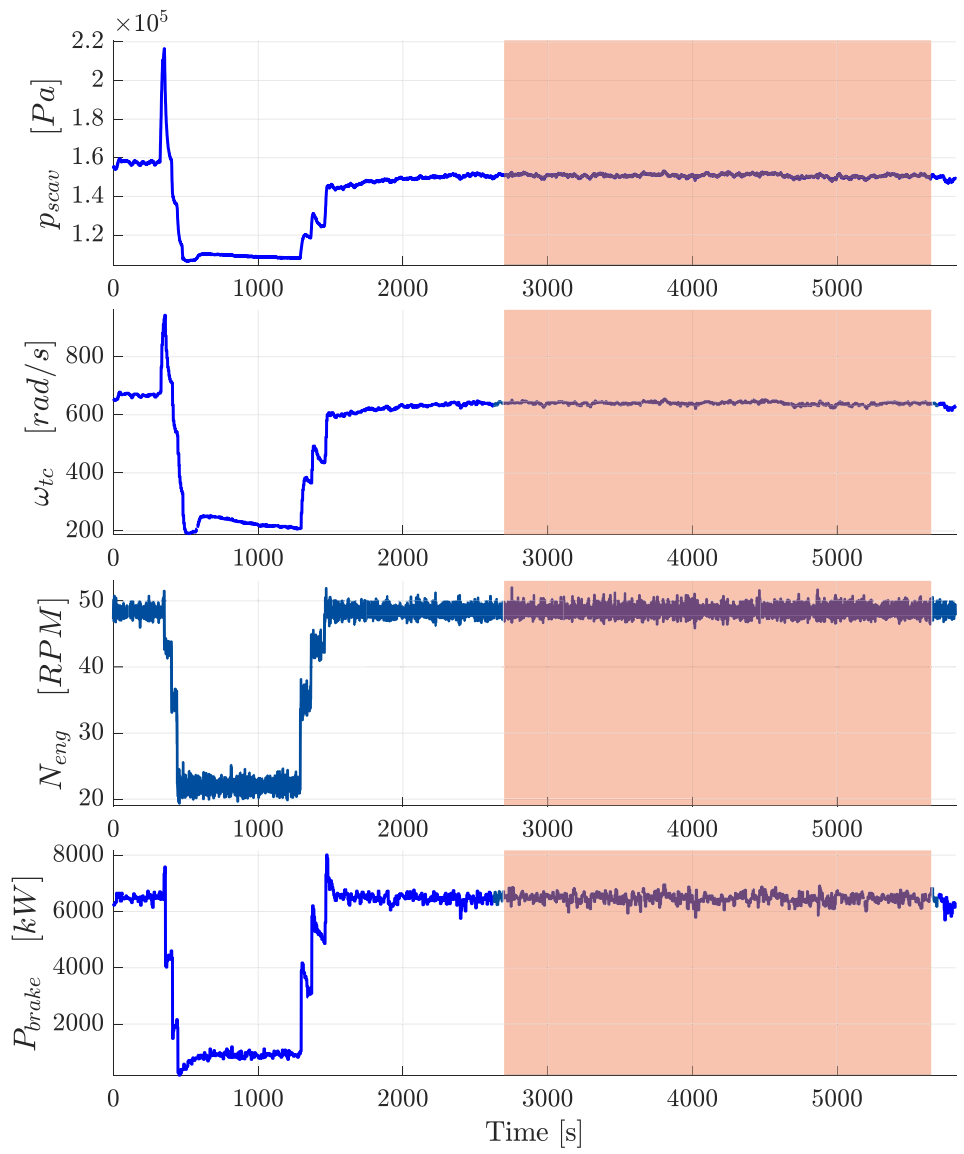

Figure 2.6: Example of a dataset containing several signals measured on a sailing ship. From top to bottom: scavenging pressure, turbocharger speed, engine speed and brake power. The time interval of an identified stationary point is highlighted in the figure.

shop test data is required for the parameterization, the simulation model can be ready to use before the engine is installed on the ship. 


\section{Publications and Main Contributions}

This chapter contains the work published by the author during the Ph.D. studies. The first section summarizes the main contributions of the papers included in the thesis. Unless explicitly stated, the first author in each paper has contributed with the majority of research work, presentation, and analysis of the results. The second section contains a list of other publications not included in the thesis, with a summary of the author's contributions.

\subsection{Summary and Contributions of the Papers Included in the Thesis}

\section{Paper 1}

Xavier Llamas and Lars Eriksson. Parameterizing Compact and Extensible Compressor Models Using Orthogonal Distance Minimization. Journal of Engineering for Gas Turbines and Power, 139(1), 2017.

The first paper describes a complete control-oriented compressor model capable of extrapolating mass flow and efficiency predictions to the unmeasured low-speed region of the compressor map. Having a reliable and extrapolation capable compressor model is a requirement for extending the load range of the two-stroke diesel engine model to low loads. The proposed compressor model is based on previous research done for automotive-size vaneless compressors, which is shown to adapt well to the characteristics of the big vaned marinesize compressors. A distinct parameterization procedure is proposed, based on minimizing the orthogonal distance between the model and the measurements. This approach is shown in the paper to overcome the difficulties that regular 
least squares have with the asymptotic behavior of the compressor maps near surge and choke regions. The model and the parameterization process are tested with nine different marine-size compressors showing a good agreement with the measured maps.

\section{Paper 2}

Xavier Llamas and Lars Eriksson. Control-Oriented Compressor Model with Adiabatic Efficiency Extrapolation. SAE International Journal of Engines, 10(4), 2017.

Paper 2 contains further improvements on the extrapolation capable controloriented compressor model described in Paper 1, using a database of more than 230 automotive compressor maps. The efficiency extrapolation is analyzed in more detail by taking into consideration that, at low speeds, the heat transfer from the hot turbine side has a significant effect on the compressor outlet temperature measurements. This issue introduces errors on the calculated efficiency, which results in lower values than it would have in adiabatic operation. The model efficiency extrapolation is analyzed, and new base functions are defined for the efficiency model to ensure proper adiabatic efficiency extrapolation at low speeds. Furthermore, the computational time of the parameterization is significantly reduced by using a Total Least Squares (TLS) approach, instead of solving geometrical projections as proposed in Paper 1. The paper includes a thorough analysis of the results, based on the parameterization of more than 230 compressor maps. In addition, the efficiency extrapolation is validated with two unique maps measured under near-adiabatic conditions at low speeds. Finally, this work serves as the basis for the development of the LiU CPgui toolbox [94], which contains the parameterization algorithm implemented in a Matlab GUI openly released for parameterizing any compressor map.

\section{Paper 3}

Guillem Alegret, Xavier Llamas, Morten Vejlgaard-Laursen, and Lars Eriksson. Modeling of a Large Marine Two-Stroke Diesel Engine with Cylinder Bypass Valve and EGR System. 10th IFAC Conference on Manoeuvring and Control of Marine Craft, Copenhagen, Denmark, 2015.

The third paper is the author's first modeling approach of a marine two-stroke diesel engine with EGR. The first two authors of the paper shared in equal parts the work of building the model and writing its description and validation. The modeled engine is the 4 T50ME-X test engine located at MAN Diesel \& Turbo Diesel Research Center in Copenhagen. The model follows the Mean Value Engine Model (MVEM) principles, where the system dynamics are given by the filling and emptying of the control volumes together with the slower turbocharger speed dynamics. The proposed MVEM is validated and shown to adapt well to the measurement data, for both stationary and dynamic conditions. However, the model is only suited for simulation from medium to high loads since the used compressor model is not capable of handling low-speed extrapolation and 
the auxiliary blower operation has to be further studied. As a result, the need for a better compressor modeling approach to improve the overall engine model is the main reason for the research carried out in Papers 1 and 2.

\section{Paper 4}

Xavier Llamas and Lars Eriksson. A Model of a Marine Two-Stroke Diesel Engine with EGR for Low Load Simulation. 9th Eurosim Congress on Modeling and Simulation, Oulu, Finland, 2016.

Paper 4 is an extension of the 4T50ME-X test engine MVEM initiated in Paper 3. The described model includes the compressor model capable of extrapolating the performance to low speeds developed in Paper 1. The new compressor model together with a model for the auxiliary blower enables the MVEM to simulate low load operation with EGR. Furthermore, the model mass fraction states are extended with more chemical species than the oxygen mass fraction, and these new states are used in the model together with the temperatures to calculate the thermodynamical properties of the gas at the different control volumes. Two test engine layouts with distinct turbochargers are used to parameterize the proposed model and to validate the model predictions, showing that the model framework is general and capable of adapting to changes in the engine components.

\section{Paper 5}

Xavier Llamas and Lars Eriksson. Control-Oriented Modeling of Two-Stroke Diesel Engines with EGR for Marine Applications. Proceedings of the Institution of Mechanical Engineers, Part M: Journal of Engineering for the Maritime Environment, 2018. In review.

Paper 5 contains further improvements in the MVEM for marine two-stroke engines with EGR, taking the model described in Paper 4 as the starting point. In this study, the modeled engine is instead the propulsion unit of a currently sailing merchant ship. New submodels for different engine components are investigated in this paper. In particular, an analytic model for the cylinder pressure that captures the influence of the fuel injection starting angle and exhaust valve opening and closing angles. This analytic model is described in detail and validated using cylinder pressure measurements. The paper contains a description of the parameterization procedure, which is done using stationary operating points extracted from measurements of the ship in standard sailing operation. Furthermore, the paper identifies essential signals to be measured in future measurement campaigns, or on other engines to simplify the parameterization process. The validation shows good agreement, both in stationary and dynamic conditions. Besides, the paper describes and validates models for the propeller and the ship surge dynamics. These models complement the diesel engine model, so it can be used as a simulation platform for analyzing controller performance during ship maneuvering scenarios. 


\section{Paper 6}

Xavier Llamas and Lars Eriksson. Robustness Analysis of the Next Generation of EGR Controllers in Marine Two-Stroke Diesel Engines. Submitted to the International Ship Control Systems Symposium, 2018.

The last paper shows how the complete dynamic vessel model from Paper 5 can be used for analyzing the robustness of new control algorithms during the development phase. The next generation of adaptive feedforward (AFF) EGR controllers from MAN Diesel \& Turbo engines is implemented, together with a new controller to follow the given EGR flow setpoint by the AFF controller. Acceleration transients at low loads are identified as the most challenging scenario for the EGR controller due to the slower engine air path dynamics. Robustness analyses in this low load area with biased control input signals and errors in the flow estimate models are performed. The simulation results indicate that sensor bias could compromise the controller, which could be prevented with accurate sensor calibration or by using a different sensor set-up for the EGR flow estimate. Errors in the parameters of the flow estimate models are also analyzed, showing that the controller performance is not as sensitive as in the sensor bias case. This result is significant because when calibrating the controller for a newly built engine, precise parameters for the flow estimators might be difficult to obtain.

\subsection{Other Publications by the Author}

A Xavier Llamas and Lars Eriksson. LiU CPgui: A Toolbox for Parameterizing Compressor Models. Technical Report Nr. LiTH-ISY-R-3102. Department of Electrical Engineering, Linköping University, SE-581 83 Linköping, Sweden, 2018.

B Lars Eriksson, Xavier Llamas, Kristoffer Ekberg, and Viktor Leek. Dynamic Modeling, Simulation and Control of Turbochargers. Chapter 6 on Turbochargers and Turbocharging: Advancements, Applications and Research, 176-206, Nova Science Publishers, 2017.

C Andreas Thomasson, Xavier Llamas, and Lars Eriksson. Turbo Speed Estimation Using Fixed-Point Iteration. SAE Technical Paper 2017-011032, Detroit, MI, USA, 2017.

D Xavier Llamas and Lars Eriksson. Optimal Transient Control of a Heavy Duty Diesel Engine with EGR and VGT. IFAC World Congress, Cape Town, South Africa, 2014.

E Xavier Llamas, Lars Eriksson, and Christofer Sundström. Fuel Efficient Speed Profiles for Finite Time Gear Shift with Multi-Phase Optimization. 54th SIMS conference, Bergen, Norway, 2013.

In general, the author's contributions to the publications mentioned above are indicated by the order in the author list, where the first author stands for the main contributor in each paper. Publication A contains the complete 
documentation, together with examples about how to work with the compressor parameterization toolbox developed from the modeling work published in Papers 1 and 2 of the thesis. The author contributed to the modeling part and the surge simulations of the book chapter listed as publication B. In publication $\mathbf{C}$, the author provided the parameterized compressor model as well as assisted the primary author with writing the article. Publications $\mathbf{D}$ and $\mathbf{E}$ correspond to research in optimal control topics from the author's beginnings as a Ph.D. student. 



\section{References}

[1] U.S. Energy Information Administration. International Energy Outlook. Number DOE/EIA-0484. 2017.

[2] International Maritime Organization. MARPOL: Annex VI and NTC 2008, 2013: with Guidelines for Implementation. IMO, 2013. ISBN 978-92-80115604.

[3] International Maritime Organization. Marine Environment Protection Committee (MEPC), 71st session, 3-7 July 2017, (Accessed: 2017-1115). http://www.imo.org/en/MediaCentre/MeetingSummaries/MEPC/ Pages/MEPC-71. aspx.

[4] International Maritime Organization. Sulphur oxides (SOx) and Particulate Matter (PM)- Regulation 14, (Accessed: 2017-11-15). http://www.imo. org/en/OurWork/Environment/PollutionPrevention/AirPollution/ Pages/Sulphur-oxides-(SOx)-\%E2\%80\%93-Regulation-14.aspx.

[5] International Maritime Organization. Energy Efficiency Measures.

[6] Daniel A. Lack, Jørgen Thuesen, and Robert Elliot. Investigation of appropriate control measures (abatement technologies) to reduce Black Carbon emissions from international shipping, 2012.

[7] P. Andreadis, A. Zompanakis, C. Chryssakis, and L. Kaiktsis. Effects of the fuel injection parameters on the performance and emissions formation in a large-bore marine diesel engine. International Journal of Engine Research, 12(1):14-29, 2011. doi: 10.1243/14680874JER511.

[8] Haiqiang Liu, Lin Lu, and Zhongjun Wang. Studying on fuel injection strategies on the performance of two-stroke marine diesel engine. In $S A E$ 
International Powertrain, Fuels \& Lubricants Meeting. SAE International, 2014. doi: 10.4271/2014-01-2706.

[9] Dimitrios T. Hountalas, Spiridon Raptotasios, Antonis Antonopoulos, Stavros Daniolos, Iosif Dolaptzis, and Maria Tsobanoglou. Two-stroke marine diesel engine variable injection timing system performance evaluation and optimum setting for minimum fuel consumption at acceptable NOx levels. In ASME 12th Biennial Conference on Engineering Systems Design and Analysis, Volume 2: Dynamics, Vibration and Control; Energy; Fluids Engineering; Micro and Nano Manufacturing, Copenhagen, Denmark, 2014. doi: 10.1115/ESDA2014-20528.

[10] Liyan Feng, Jiangping Tian, Wuqiang Long, Weixin Gong, Baoguo Du, Dan $\mathrm{Li}$, and Lei Chen. Decreasing NOx of a low-speed two-stroke marine diesel engine by using in-cylinder emission control measures. Energies, 9(4), 2016. ISSN 1996-1073. doi: 10.3390/en9040304.

[11] Svend Henningsen. Influence of the fuel injection equipment on NOx emissions and particulates on a large heavy-duty two-stroke diesel engine operating on water-in-fuel emulsion. In SAE Technical Paper 941783. SAE International, 1994. doi: 10.4271/941783.

[12] Franz X. Tanner, Matthias Brunner, and German Weisser. A computational investigation of water injection strategies for nitric oxide reduction in large-bore DI diesel engines. In SAE Technical Paper 2001-01-1069. SAE International, 2001. doi: 10.4271/2001-01-1069.

[13] Christos Chryssakis, Lambros Kaiktsis, and Athanasios Frangopoulos. Computational investigation of in-cylinder $\mathrm{NOx}$ emissions reduction in a large marine diesel engine using water addition strategies. In SAE Technical Paper 2010-01-125\%. SAE International, 2010. doi: 10.4271/2010-01-1257.

[14] Marcel Ott, Ingemar Nylund, Roland Alder, Takayuki Hirose, Yoshiyuki Umemoto, and Takeshi Yamada. The 2-stroke low-pressure dual-fuel technology: From concept to reality. In 28th CIMAC World Congress on Combustion Engine, 2016.

[15] Takashi Unseki. Environmentally superior LNG-Fueled vessels. Mitsubishi Heavy Industries Technical Review, pages 37-43, 2013.

[16] Kristoffer Sandelin and Daniel Peitz. SCR under pressure - pre-turbocharger NOx abatement for marine 2-stroke diesel engines. In 28th CIMAC World Congress on Combustion Engine, 2016.

[17] Changseong Ryu, Jinwoo Hwang, Jinho Cheon, Jongtae Choi, and Sangjin Kim. The world's first commercialized low pressure scr system on 2-stroke engine. In 28th CIMAC World Congress on Combustion Engine, 2016.

[18] John B. Heywood. Internal Combustion Engine Fundamentals. McGrawHill, 1988. 
[19] Haifeng Liu, Huixiang Zhang, Hu Wang, Xian Zou, and Mingfa Yao. A numerical study on combustion and emission characteristics of marine engine through miller cycle coupled with EGR and water emulsified fuel. In $S A E$ International Powertrains, Fuels \& Lubricants Meeting. SAE International, 2016. doi: 10.4271/2016-01-2187.

[20] Chen Wang, Tianyou Wang, Kai Sun, Zhen Lu, and Yong Gui. Effects of EGR and injection strategies on the performance and emissions of a two-stroke marine diesel engine. In SAE International Powertrains, Fuels \& Lubricants Meeting. SAE International, 2017.

[21] Xiuxiu Sun, Xingyu Liang, Gequn Shu, Jiansheng Lin, Yuesen Wang, and Yajun Wang. Numerical investigation of two-stroke marine diesel engine emissions using exhaust gas recirculation at different injection time. Ocean Engineering, 144(Supplement C):90 - 97, 2017. ISSN 0029-8018. doi: 10.1016/j.oceaneng.2017.08.044.

[22] Masahiko Okabe, Katsuhiko Sakaguchi, Masahide Sugihara, Akihiro Miyanagi, Naohiro Hiraoka, and Satoru Murata. The world's largest marine 2-stroke diesel test engine, the 4UE-X3 - development in compliance with the next version of environmental regulations and gas engine technology. Mitsubishi Heavy Industries Technical Review, pages 55-62, 2013.

[23] Naohiro Hiraoka, Akihiro Miyanagi, Kentaro Kuroda, Kazuhisa Ito, Takahiro Nakagawa, and Takashi Ueda. The world's first onboard verification test of UE engine with low pressure EGR complied with IMO's NOx tier III regulations. Mitsubishi Heavy Industries Technical Review, pages 40-47, 2016.

[24] Kræn Vodder Nielsen. Exhaust Recirculation Control for Reduction of NOx from Large Two-Stroke Diesel Engines. PhD thesis, Technical University of Denmark, 2016.

[25] Kræn Vodder Nielsen, Mogens Blanke, Lars Eriksson, and Morten VejlgaardLaursen. Adaptive feedforward control of exhaust recirculation in large diesel engines. Control Engineering Practice, 65:26 - 35, 2017. ISSN 0967-0661. doi: 10.1016/j.conengprac.2017.05.003.

[26] Kræn Vodder Nielsen, Mogens Blanke, Lars Eriksson, and Morten VejlgaardLaursen. Diesel engine control system to meet strict emission requirements while maintaining full ship manoeuvring capability. Applied Energy, 2016. Submitted.

[27] Hercules-2. Fuel flexible, near-zero emissions, adaptive performance marine engine, (Accessed: 2017-11-29). http://cordis.europa.eu/project/rcn/ 196603_en.html.

[28] LINK-SIC. Linköping Center for Sensor Informatics and Control., (Accessed: 2018-01-12). http://www.linksic.isy.liu.se/. 
[29] Nikolaos Xiros. Robust Control of Diesel Ship Propulsion. Springer-Verlag London, 2002.

[30] Doug Woodyard. Pounder's Marine Diesel Engines and Gas Turbines. Butterworth-Heinemann, 9th edition, 2009. ISBN 9780750689847.

[31] Gequn Shu, Youcai Liang, Haiqiao Wei, Hua Tian, Jian Zhao, and Lina Liu. A review of waste heat recovery on two-stroke IC engine aboard ships. Renewable and Sustainable Energy Reviews, 19:385 - 401, 2013. ISSN 1364-0321. doi: 10.1016/j.rser.2012.11.034.

[32] Winterthur Gas \& Diesel. Low-speed Engines. 2017.

[33] MAN Diesel \& Turbo. Marine Engine IMO Tier II and Tier III Programme 2nd edition, September 2017. Publication no. 4510-0016-01web.

[34] Mitsubishi Heavy Industries. UE Engines, (Accessed: 2017-11-13). https: //www.-mme.com/products/engine/.

[35] Gordon P. Blair. Design and simulation of two-stroke engines. SAE, 1996. ISBN 1-56091-685-0.

[36] John B. Heywood and Eran Sher. The two-stroke cycle engine. SAE Combustion: An international series, 1999. ISBN 1-56032-831-2.

[37] Fabio Scappin, Sigurður H. Stefansson, Fredrik Haglind, Anders Andreasen, and Ulrik Larsen. Validation of a zero-dimensional model for prediction of NOx and engine performance for electronically controlled marine two-stroke diesel engines. Applied Thermal Engineering, 37(Supplement C):344 - 352, 2012. ISSN 1359-4311. doi: /10.1016/j.applthermaleng.2011.11.047.

[38] Spiridon I. Raptotasios, Nikolaos F. Sakellaridis, Roussos G. Papagiannakis, and Dimitrios T. Hountalas. Application of a multi-zone combustion model to investigate the NOx reduction potential of two-stroke marine diesel engines using EGR. Applied Energy, 157:814 - 823, 2015. ISSN 0306-2619. doi: 10.1016/j.apenergy.2014.12.041.

[39] Nikolaos Stamoudis, Christos Chryssakis, and Lambros Kaiktsis. A twocomponent heavy fuel oil evaporation model for CFD studies in marine diesel engines. Fuel, 115(Supplement C):145 - 153, 2014. ISSN 0016-2361. doi: $10.1016 /$ j.fuel.2013.06.035.

[40] Xiuxiu Sun, Xingyu Liang, Gequn Shu, Yajun Wang, Yuesen Wang, and Hanzhengnan $\mathrm{Yu}$. Effect of different combustion models and alternative fuels on two-stroke marine diesel engine performance. Applied Thermal Engineering, 115(Supplement C):597 - 606, 2017. ISSN 1359-4311. doi: 10.1016/j.applthermaleng.2016.12.093.

[41] Lei Zhou, Aifang Shao, Haiqiao Wei, and Xi Chen. Sensitivity analysis of heavy fuel oil spray and combustion under low-speed marine engine-like conditions. Energies, 10(8), 2017. ISSN 1996-1073. doi: 10.3390/en10081223. 
[42] Congbiao Sui, Enzhe Song, Douwe Stapersma, and Yu Ding. Mean value modelling of diesel engine combustion based on parameterized finite stage cylinder process. Ocean Engineering, 136:218 - 232, 2017. ISSN 0029-8018. doi: 10.1016/j.oceaneng.2017.03.029.

[43] Xavier Llamas and Lars Eriksson. Control-oriented modeling of two-stroke diesel engines with EGR for marine applications. Proc. Inst. Mech. Eng. M: Journal of engineering for the maritime environment, 2018. In review.

[44] Lars Eriksson and Ingemar Andersson. An analytic model for cylinder pressure in a four stroke SI engine. In SAE Technical Paper 2002-01-0371. SAE International, mar 2002. doi: 10.4271/2002-01-0371.

[45] A.J. Murphy, A.J. Norman, K. Pazouki, and D.G. Trodden. Thermodynamic simulation for the investigation of marine diesel engines. Ocean Engineering, 102:117 - 128, 2015. ISSN 0029-8018. doi: 10.1016/j.oceaneng.2015.04.004.

[46] G. P. Merker and M. Gerstle. Evaluation on two stroke engines scavenging models. In SAE Technical Paper 970358. SAE International, feb 1997. doi: $10.4271 / 970358$.

[47] Sajjad Haider. Experimental and Numerical Study of Swirling Flow in Scavenging Process for 2-Stroke Marine Diesel Engines. PhD thesis, Technical University of Denmark, 2011.

[48] E. Sigurdsson, K.M. Ingvorsen, M.V. Jensen, S. Mayer, S. Matlok, and J.H. Walther. Numerical analysis of the scavenge flow and convective heat transfer in large two-stroke marine diesel engines. Applied Energy, 123:37 46, 2014. ISSN 0306-2619. doi: 10.1016/j.apenergy.2014.02.036.

[49] María Isabel Lamas and Carlos Gervasio Rodíguez Vidal. Computational fluid dynamics analysis of the scavenging process in the MAN B\&W 7S50MC two-stroke marine diesel engine. Journal of Ship Research - Society of Naval Architects and Marine Engineers, 56(3):154-161, 2012. ISSN 0022-4502. doi: doi:10.5957/JOSR.56.3.120001.

[50] Frederik Herland Andersen. Integrated Analysis of the Scavenging Process in Marine Two-Stroke Diesel Engines. PhD thesis, Technical University of Denmark, 2015.

[51] John B. Woodward and Robert G. Latorre. Modeling of diesel engine transient behavior in marine propulsion analysis. Transactions - Society of Naval Architects and Marine Engineers, 92:33 - 49, 1985.

[52] M. Blanke and J. A. Anderson. On modelling large two stroke diesel engines: new results from identification. IFAC Proceedings Series, pages 2015-2020, 1985.

[53] Elbert Hendricks. A compact, comprehensive model of a large turbocharged, two-stroke diesel engine. In SAE Technical Paper. SAE, 1986. doi: 10.4271/ 861190 . 
[54] Lars Eriksson and Lars Nielsen. Modeling and Control of Engines and Drivelines. John Wiley \& Sons, 2014.

[55] Lino Guzzella and Christopher H. Onder. Introduction to Modeling and Control of Internal Combustion Engine Systems. Springer Berlin Heidelberg, 2nd edition, 2010.

[56] Gerasimos Theotokatos. On the cycle mean value modelling of a large two-stroke marine diesel engine. Proc. Inst. Mech. Eng. M: Journal of engineering for the maritime environment, 224(3):193-206, 2010. ISSN 1475-0902. doi: 10.1243/14750902JEME188.

[57] Nikolaos I. Xiros and Gerasimos Theotokatos. Improved transient control of a two-stroke marine diesel engine with variable geometry turbine. In $A S M E$ 2011 Internal Combustion Engine Division Fall Technical Conference, West Virginia, USA, 2011. doi: 10.1115/ICEF2011-60199.

[58] Cong Guan, Gerasimos Theotokatos, Peilin Zhou, and Hui Chen. Computational investigation of a large containership propulsion engine operation at slow steaming conditions. Applied Energy, 130:370 - 383, 2014. ISSN 0306-2619. doi: 10.1016/j.apenergy.2014.05.063.

[59] Gerasimos Theotokatos and Vasileios Tzelepis. A computational study on the performance and emission parameters mapping of a ship propulsion system. Proc. Inst. Mech. Eng. M: Journal of engineering for the maritime environment, 229(1):58-76, 2015. doi: 10.1177/1475090213498715.

[60] Andreas Torp Karlsen. On Modeling of a Ship Propulsion System for Control Purposes. Master's thesis, NTNU, Trondheim, 2012.

[61] Zhe Tian, Xin Ping Yan, and Ye Ping Xiong. Turbocharged two-stroke diesel engine of large vessels modeling and simulation. In Advances in Computing, Control and Industrial Engineering, volume 235 of Applied Mechanics and Materials, pages 233-238. Trans Tech Publications, 122012. doi: 10.4028/www.scientific.net/AMM.235.233.

[62] Jianyuan Zhu. Modeling and simulating of container ship's main diesel engine. In International MultiConference of Engineers and Computer Scientists, IMECS, Hong Kong, 2008.

[63] N.P. Kyrtatos, G. Theotokatos, N.I. Xiros, K. Marek, and R. Duge. Transient operation of large-bore two-stroke marine diesel engine powerplants: measurements and simulations. In 23rd CIMAC World Congress on Combustion Engine, volume 4, pages 1237-1250, Hamburg, Germany, 2001.

[64] N.P. Kyrtatos, G. Theotokatos, and N.I. Xiros. A virtual experiment tool for marine diesel engine powerplant analysis. In 10th International Congress of the International Maritime Association of the Mediterranean (IMAM 2002), volume 4, pages 1237-1250, Crete, Greece, 2002.

[65] N.P. Kyrtatos. MOtor THERmodynamics ver 1.3 - user manual, 1999. 
[66] A. G. Livanos, G. Theotokatos, and N. P. Kyrtatos. Simulation of large marine two-stroke diesel engine operation during fire in the scavenging air receiver. Journal of Marine Engineering \& Technology, 2(2):9-16, 2003. doi: 10.1080/20464177.2003.11020170.

[67] Cong Guan, Gerasimos Theotokatos, and Hui Chen. Analysis of two stroke marine diesel engine operation including turbocharger cut-out by using a zero-dimensional model. Energies, 8(6):5738 - 5764, 2015. doi: $10.3390 /$ en8065738.

[68] Gerasimos Theotokatos, Cong Guan, Hui Chen, and Iraklis Lazakis. Development of an extended mean value engine model for predicting the marine two-stroke engine operation at varying settings. Energy, 143:533 - 545, 2018. ISSN 0360-5442. doi: 10.1016/j.energy.2017.10.138.

[69] Kevin Koosup Yum, Bhushan Taskar, Eilif Pedersen, and Sverre Steen. Simulation of a two-stroke diesel engine for propulsion in waves. International Journal of Naval Architecture and Ocean Engineering, 9(4):351 - 372, 2017. ISSN 2092-6782. doi: 10.1016/j.ijnaoe.2016.08.004.

[70] Christoforos Mavrelos and Gerasimos Theotokatos. Modelling and parametric investigation of a large marine two-stroke dual fuel engine. In ISME2017 - The 11th International Symposium of Marine Engineering, pages 174-179, Tokyo, Japan, 2017.

[71] Christoforos Mavrelos and Gerasimos Theotokatos. Numerical investigation of a premixed combustion large marine two-stroke dual fuel engine for optimising engine settings via parametric runs. Energy Conversion and Management, 160:48 - 59, 2018. ISSN 0196-8904. doi: 10.1016/j.enconman. 2017.12.097.

[72] Yuanyuan Tang, Jundong Zhang, Huibing Gan, Baozhu Jia, and Yu Xia. Development of a real-time two-stroke marine diesel engine model with in-cylinder pressure prediction capability. Applied Energy, 194(Supplement C):55 - 70, 2017. ISSN 0306-2619. doi: 10.1016/j.apenergy.2017.03.015.

[73] N. Watson and M.S. Janota. Turbocharging the internal combustion engine. MacMillan, London, 1982.

[74] E Meier. A simple method of calculation and matching turbochargers. In Publication no. CH-T 120 163E, Baden, Brown Boveri \& Company Ltd, 1981.

[75] J.R. Serrano, F.J. Arnau, V. Dolz, A. Tiseira, and C. Cervelló. A model of turbocharger radial turbines appropriate to be used in zero- and onedimensional gas dynamics codes for internal combustion engines modelling. Energy Conversion and Management, 49(12):3729 - 3745, 2008. ISSN 0196-8904. doi: 10.1016/j.enconman.2008.06.031. 
[76] Karla Stricker, Lyle Kocher, Ed Koeberlein, D.G. Van Alstine, and Gregory M. Shaver. Turbocharger map reduction for control-oriented modeling. ASME J Dyn Sys Meas Control, 136(4), April 2014. doi: 10.1115/1.4026532.

[77] Andreas Sidorow, Rolf Isermann, Francesco Cianflone, and Gerhard Landsmann. Comparison of a turbocharger model based on isentropic efficiency maps with a parametric approach based on euler's turbo-machinery equation. IFAC Proceedings Volumes, 44(1):10627 - 10632, 2011. ISSN 1474-6670. doi: 10.3182/20110828-6-IT-1002.03584. 18th IFAC World Congress.

[78] Lars Eriksson. Modeling and control of turbocharged SI and DI engines. Oil $\&$ Gas Science and Technology, 62(4):523-538, October 2007. doi: 10.2516/ogst:2007042.

[79] Xavier Llamas and Lars Eriksson. A model of a marine two-stroke diesel engine with EGR for low load simulation. In 9th EUROSIM Congress on Modelling and Simulation, Oulu, Finland, 2016.

[80] P. Mizythras, E. Boulougouris, and G. Theotokatos. Computational investigation of ship propulsion performance in rough seas. In MSO2016 International Conference of Maritime Safety and Operations 2016, pages 183-193, Glasgow, United Kingdom, 2016.

[81] Xavier Llamas and Lars Eriksson. Parameterizing compact and extensible compressor models using orthogonal distance minimization. ASME J Gas Turb Pwr, 139(1), 2017. doi: 10.1115/1.4034152.

[82] Xavier Llamas and Lars Eriksson. Control-oriented compressor model with adiabatic efficiency extrapolation. SAE International Journal of Engines, $10(4), 2017$.

[83] Oskar Leufvén and Lars Eriksson. Measurement, analysis and modeling of centrifugal compressor flow for low pressure ratios. Int. J. Engine Res., 17 (2):153-168, February 2016. doi: 10.1177/1468087414562456.

[84] Guillaume Martin, Vincent Talon, Pascal Higelin, Alain Charlet, and Christian Caillol. Implementing turbomachinery physics into data map-based turbocharger models. SAE Int. J. of Engines, 2(1):211-229, April 2009. doi: 10.4271/2009-01-0310.

[85] Johan Wahlström, Lars Eriksson, and Lars Nielsen. EGR-VGT control and tuning for pumping work minimization and emission control. IEEE Transactions on Control Systems Technology, 18(4):993-1003, 2010.

[86] Johan Kaltoft and Mikkel Preem. Development of integrated EGR system for two-stroke diesel engines. In 27th CIMAC World Congress on Combustion Engine, 2013.

[87] MAN Diesel \& Turbo. Emission Project Guide, October 2017. Publication no. 7020-0145-08ppr. 
[88] Jakob Mahler Hansen, Claes-Göran Zander, Nicolai Pedersen, Mogens Blanke, and Morten Vejlgaard-Laursen. Modelling for control of exhaust gas recirculation on large diesel engines. 9th IFAC Conference on Control Applications in Marine Systems, 2013. doi: 10.3182/20130918-4-JP-3022. 00013.

[89] Johan Wahlström and Lars Eriksson. Modelling diesel engines with a variable-geometry turbocharger and exhaust gas recirculation by optimization of model parameters for capturing non-linear system dynamics. Proceedings of the Institution of Mechanical Engineers, Part D, Journal of Automobile Engineering, 225(7):960-986, 2011.

[90] Guillem Alegret, Xavier Llamas, Morten Vejlgaard-Laursen, and Lars Eriksson. Modeling of a large marine two-stroke diesel engine with cylinder bypass valve and EGR system. IFAC-PapersOnLine, 48(16):273 - 278, 2015. ISSN 2405-8963. doi: 10.1016/j.ifacol.2015.10.292. 10th IFAC Conference on Manoeuvring and Control of Marine Craft.

[91] Zhanguang Wang, Song Zhou, Yongming Feng, and Yuanqing Zhu. Research of NOx reduction on a low-speed two-stroke marine diesel engine by using EGR (exhaust gas recirculation) - CB (cylinder bypass) and EGB (exhaust gas bypass). International Journal of Hydrogen Energy, 42(30):19337 19345, 2017. ISSN 0360-3199. doi: 10.1016/j.ijhydene.2017.06.009.

[92] Zhanguang Wang, Song Zhou, Yongming Feng, and Yuanqing Zhu. Investigation of EGR with EGB (exhaust gas bypass) on low speed marine diesel engine performance and emission characteristics. In ASME International Conference on Offshore Mechanics and Arctic Engineering, Trondheim, Norway, 2017. doi: 10.1115/OMAE2017-62606.

[93] Fotis Kyriakidis, Kim Sørensen, Shobhana Singh, and Thomas Condra. Modeling and optimization of integrated exhaust gas recirculation and multi-stage waste heat recovery in marine engines. Energy Conversion and Management, 151:286 - 295, 2017. ISSN 0196-8904. doi: 10.1016/j. enconman.2017.09.004.

[94] Xavier Llamas and Lars Eriksson. LiU CPgui: A toolbox for parameterizing compressor models. Technical Report LiTH-ISY-R-3102, Department of Electrical Engineering, Linköpings University, SE-581 83 Linköping, Sweden, 2018. 


\section{Papers}

The papers associated with this thesis have been removed for copyright reasons. For more details about these see:

http://urn.kb.se/resolve?urn=urn:nbn:se:liu:diva-144596 